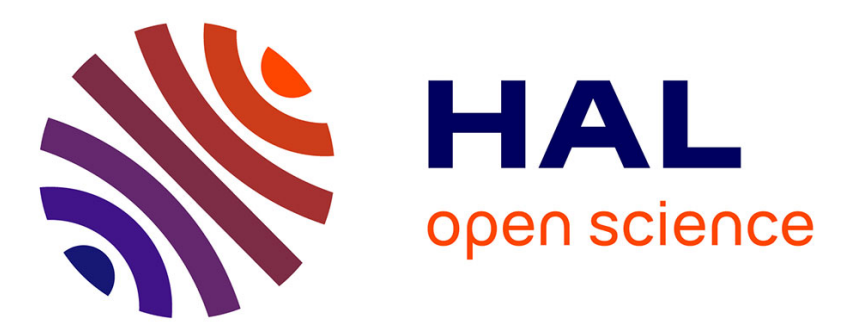

\title{
Design of a photo-written cavity neodymium doped fibre laser, tunable around a particular absorption molecular line
}

G. Martinelli, M. Douay, P. Bernage, P. Niay, J. Henninot, P. Carette, J. Bayon

\section{To cite this version:}

G. Martinelli, M. Douay, P. Bernage, P. Niay, J. Henninot, et al.. Design of a photo-written cavity neodymium doped fibre laser, tunable around a particular absorption molecular line. Journal de Physique IV Proceedings, 1994, 04 (C4), pp.C4-719-C4-719. 10.1051/jp4:19944197 . jpa-00252658

\section{HAL Id: jpa-00252658 https://hal.science/jpa-00252658}

Submitted on 1 Jan 1994

HAL is a multi-disciplinary open access archive for the deposit and dissemination of scientific research documents, whether they are published or not. The documents may come from teaching and research institutions in France or abroad, or from public or private research centers.
L'archive ouverte pluridisciplinaire HAL, est destinée au dépôt et à la diffusion de documents scientifiques de niveau recherche, publiés ou non, émanant des établissements d'enseignement et de recherche français ou étrangers, des laboratoires publics ou privés. 


\title{
Design of a photo-written cavity neodymium doped fibre laser, tunable around a particular absorption molecular line
}

\author{
G. MARTINELII, M. DOUAY, P. BERNAGE, P. NIAY, J.F. HENNINOT ${ }^{*}$, P. CARETTE* and \\ J.F. BAYON ${ }^{* *}$
}

Laboratoire de Dynamique Moléculaire et Photonique, URA 779, Université de Lille I, France

${ }^{*}$ Laboratoire de Photonique, Faculté des Sciences, Jean Perrin, Université d'Artois, Lens, France

${ }^{* *}$ Lab/O.C.M./F.O.G./C.N.E.T., Lannion, France

\begin{abstract}
:
Experimental works have shown it is possible to realize photo-written cavity lasers with rare earth doped silicate fibres. Most of these new laser sources can be pumped by market laser diodes, what makes them valuables for their integretion in system. Furthermore, their laser effect threshold (1-2 $\mathrm{mW}$ ), their spectral width (a few Ghz), their conversion rate, close to the theorical value and their wavelength tunablelity allow their use in a wide range of applications such as telecommunications, sensors; etc ...

We present here experimental results on a particular application of this kind of lasers in the field of detection of a gas by identification of one of its absorption lines by use of classical linear spectroscopic methods. We have carried out our experiments on an absorption line of water.

We present first the making process of the fibre lasers and the method used to insure their tunablelity around the selected absorption line of water. Two lasers have been designed for this work. We give their respective characteristics, i.e. their spectral width, slope, polarisation state and we compare them with the theorical values.

Secondly, we give the absorption spectra obtained with both these lasers scanning their wavelength. These spectra consist on the detected light intensity versus the laser wavelength with the laser beam freely propagating through a few meters of absorbing medium.

At least, we present the preliminary experimental results on the optoacoustics detection of an absorption line of water obtained using the fibre laser having the best characteristics. The obtained curve gives the detected acoustic power versus scanned wavelength range using a non optimized acoustic cell of a few $\mathrm{cm}$ long containing air at room pressure and temperature.
\end{abstract}

